\section{Sciensage}

Journal of Advanced Scientific Research

Available online through https: / /sciensage.info
ISSN: 0976-9595

Research Article

DOI: $10.55218 /$ JASR. 202213133

\title{
ANTIOXIDANT POTENTIAL AND CHROMATOGRAPHIC PROFILING OF COUROUPITA GUIANENSIS FRUIT PULP
}

\author{
Anuradha Venkatraman**1, Lawrence Anna Sheba ${ }^{1,2}$ \\ ${ }^{1}$ Department of Biochemistry, Mohamed Sathak College of Arts and Science, Chennai, Tamilnadu, India \\ ${ }^{2}$ Department of Biochemistry, Soka Ikeda College of Arts and Science for Women, Chennai, Tamilnadu, India \\ *Corresponding author: vanuradha2712@gmail.com
}

\begin{abstract}
Cannonball (Couroupita guianensis) fruits are large sized with disagreeable odor. However, it is widely used traditionally for cold, wound, headache, stomach ache, antibacterial, antifungal and medicinal drink. The present investigation was focused to determine the total phenol and flavonoids as well as the antioxidant properties of fruit pulp of Couroupita guianensis extracted with four different solvents. Additionally, chemical constituents of fruit pulp were also evaluated. Successful extraction was carried out with different solvents such as petroleum ether, chloroform, ethanol and aqueous alcohol using Soxhlet apparatus. The different extracts were assessed for quantitative total phenol and total flavonoid contents, and their antioxidant activity were determined by DPPH (2, 2-diphenyl-1-picryl-hydrazyl-hydrate) assay. The extract presenting higher total phenol and flavonoid was subjected to Gas chromatography coupled with Mass Spectrometry (GC-MS) to explore the chemical constituents. Ethanol extract presented higher total phenol and total flavonoid and was found to be $206.98 \pm 0.40 \mathrm{mg}$ GAE/g and $83.18 \pm 0.42 \mathrm{mg}$ QE/g respectively. Similarly, \% inhibition of DPPH was higher in the ethanol extract exhibiting $\mathrm{IC}_{50}$ value of 52.59. GC-MS analysis confirmed the presence of about 30 different chemical components. Among the different components, 2,5-Furandione, 3 methyl and hydroxymethylfurfural were found to be the major components in the ethanol extract. The present investigation confirmed that the ethanol extract had showed higher total phenol and flavonoid which can be correlated to its highest \% inhibition than other extracts. Hence, considering the obtained result, the ethanol extract can be explored for pharmacological activities.
\end{abstract}

Keywords: Antioxidant, Couroupita guianensis, GC-MS, Flavonoids, Phenolic compounds.

\section{INTRODUCTION}

In recent years, humankind has been developing interest on natural occurring bioactive constituents due to their lesser side effects. Plants are the richest source of bioactive compounds, the so-called secondary metabolites [1]. These secondary metabolites have the potential to act against free radicals and hence they are considered as antioxidants [2]. Oxidants like reactive oxygen species (ROS) and reactive oxygen nitrogen species (RONS) are produced naturally in the human body as a part of metabolic process [3]. Imbalance between the oxidants and natural process to detoxify these oxidants will prompt the production of free radicals resulting in severe damage to the cells, thus leading to oxidative stress. Naturally occurring antioxidants can help to reduce the generation of free radicals. The antioxidants quench these free radicals, thereby able to prevent oxidative stress related diseases
[4]. This encouraged scientist to perform various studies in different plant extracts to investigate the phytocomponents and their pharmacological role. Couroupita guianensis (Family: Lecythidaceae) is commonly referred as cannonball tree. It is widely distributed in South America, Central America, India, Srilanka and Malaysia. In India, it is widely grown in Shiva temples and hence known as sacred tree. It is popular among tribes and rural people and these people used different parts of this plant for treating various human ailments including hypertension, scorpion sting, toothache, inflammatory processes, tumors, kidney and stomach problems, allergies, hemorrhage, piles, dysentery, ulcers, scabies, and skin diseases. There are scientific reports to validate its traditional and pharmacological uses. C. guianensis is a gigantic tree bearing huge sized fruit, and scented and glamorous flowers. Seeds are used to propagate the plant. The fruit pulp is embedded with numerous seeds. 
The fruit pulp is rich in alkaloid, phenolic compounds and flavonoids which are reported to possess antioxidant activity [5]. To our knowledge, there is still inadequate information regarding the phytocomponents of fruit pulp. Currently, for investigating phytocomponents, researchers commonly employs Gas chromatography coupled with Mass spectrometry as it has been proved to be a valuable technique to assess nonpolar and volatile components [6]. The correlation between the phytocomponents and antioxidant activity renews interest to design a study regarding the total phenolic and flavonoid contents as well as the antioxidant activities of $C$. guianensis fruit pulp extracted with four different solvents (petroleum ether, chloroform, ethanol and hydroalcohol). In addition, the chemical composition of $C$. guianensis fruit pulp was evaluated by GC-MS to achieve in-depth knowledge about the phytoconstituents of fruit pulp.

\section{MATERIAL AND METHODS}

\subsection{Sample selection}

C. guianensis fruit was collected from the Ayurveda research center, Kerala during the months of October and November. The fruits were then selected such that they were free from fungal infection. The selected fruits were shade dried, ground and stored. The powder was used for further analysis.

\subsection{Preparation of extract}

Processing of the powdered sample was carried out by following hot percolation method. The finely ground sample was extracted using a soxhlet apparatus with 4 different solvents such as petroleum ether, chloroform, ethanol and hydroalcohol. The extracts were then subjected to rotary evaporator and the final extracts obtained were stored at $4^{\circ} \mathrm{C}$ for further use.

\subsection{Quantitative phytochemical analysis}

The extracts were analyzed for total phenol and flavonoid quantitatively. Spectrophotometric determination of total phenolic content in all the extracts was carried out using Folin-Ciocalteu's phenol reagent and gallic acid as standard [7]. The phenol content was estimated using the calibration curve equation, $\mathrm{y}=0.0044 \times+0.2663, \mathrm{R}^{2}=0.9962$. Similarly, determination of flavonoid content was carried out with quercetin as standard [8]. The flavonoid content was determined from the quercetin calibration graph equation, $\mathrm{y}=0.0021 \times+0.1617, \mathrm{R}^{2}=0.9735$.

\subsection{Determination of antioxidant activity}

The antioxidant property of the fruit pulp extracts was evaluated by carrying out DPPH (2, 2-diphenyl-1picryl-hydrazyl-hydrate) free radical scavenging assay. The extracts were subjected to DPPH radical scavenging assay using a modified method described by Perumal et al., 2018 [9]. Different concentrations (5, 10, 20, 40 and $80 \mu \mathrm{g} / \mathrm{mL}$ ) of the extracts were mixed with $2.5 \mathrm{~mL}$ of DPPH solution. The mixture was shaken well and incubated at room temperature for $30 \mathrm{~min}$. The absorbance of the mixture was measured at $517 \mathrm{~nm}$. Ascorbic acid was used as the standard. The following formula was able to determine the ability of the extract and standard to scavenge DPPH radical.

$\%$ DPPH inhibition $=[(\mathrm{OD}$ of control $-\mathrm{OD}$ of test $) /$ (OD of control) $] \times 100$

The extract concentration with $50 \%$ of radicalscavenging activity $\left(\mathrm{IC}_{50}\right)$ was determined from the graph by plotting \% scavenging inhibition against extract concentration.

\subsection{GC-MS analysis}

GC-MS spectrum of the ethanol extract was recorded in gas chromatography coupled with mass spectrometry GC 17A- QP 5000 (Shimadzu) instrument. Capillary column $(30 \mathrm{~m}$ in length $\mathrm{X} 0.25 \mathrm{~mm} ; 0.1 \mu \mathrm{m}$ in thickness) was used. The operation condition of the column was set at $60^{\circ} \mathrm{C}$ as initial temperature. The temperature then was increased up to $300^{\circ} \mathrm{C}$ at a rate of $20^{\circ} \mathrm{C} / \mathrm{min}$. The column was maintained at a pressure of $100 \mathrm{KPa}$. Helium was used as the carrier gas. About 0.1 $\mu \mathrm{l}$ of the sample dissolved in suitable solvent was injected along with helium gas at a flow rate of 0.6 $\mathrm{ml} / \mathrm{min}$. Identification of the compounds were carried out based on the retention time and by comparing the spectrum using Wiley and NIST spectral library search programme.

\subsection{Statistical analysis}

All the data observed in each experiment included 3 replicates and the results were expressed as mean \pm SE. The data was compared using one-way analysis of variance (ANOVA) and statistically significant differences were determined by Tukey's test using Graphpad Prism.

\section{RESULTS AND DISCUSSION}

Various solvents have been utilized to extract phenol and flavonoid from the fruit pulp of $C$. guianensis. 
Phenols are secondary metabolites with wide antioxidant activities. Higher antioxidant activities of phenol may be attributed to their hydrogen groups that can act as hydrogen donor. This reducing property makes it to function as radical scavenger [10]. In the present study, the content of phenol in the extracts was determined with reference to gallic acid equivalents per gram (GAE/g). The result clearly showed that the solvents had different capabilities to extract the phenols from the sample. The ethanol extract had the highest phenol content of $206.97 \pm 0.568 \mathrm{mg} \mathrm{GAE} / \mathrm{g}$ while the petroleum ether extract had the lowest content of $8.95 \pm 0.367 \mathrm{mg} \mathrm{QE} / \mathrm{g}$ (table 1).

Table 1: Total phenolic and flavonoid content of different solvent extracts of $C$. guianensis fruit pulp

\begin{tabular}{ccc}
\hline Extract & $\begin{array}{c}\text { Total phenolic } \\
\text { content } \\
(\mathrm{mg} \mathrm{GAE} / \mathrm{g})\end{array}$ & $\begin{array}{c}\text { Total flavonoid } \\
\text { content } \\
(\mathrm{mg} \mathrm{QE} / \mathrm{g})\end{array}$ \\
\hline Petroleum ether & $8.95 \pm 0.367^{\mathrm{a}}$ & $38.49 \pm 0.927^{\mathrm{a}}$ \\
\hline Chloroform & $49.40 \pm 0.371^{\mathrm{b}}$ & $51.08 \pm 0.348^{\mathrm{b}}$ \\
\hline Ethanol & $206.97 \pm 0.568^{\mathrm{c}}$ & $83.18 \pm 0.604^{\mathrm{c}}$ \\
\hline Hydroalcohol & $100.16 \pm 0.57^{\mathrm{d}}$ & $77.99 \pm 0.608^{\mathrm{d}}$ \\
\hline Values are Mean \pm Standard error of three replicates. Means followed by \\
same letters are statistically not significant at $\alpha=0.05$ by Tukey test.
\end{tabular}

The higher amount of phenol content in the ethanol extract confirmed the ethanol as a good solvent in extracting phenol from the sample. Further, lowest amount of phenol content in the petroleum ether extract enabled to consider that petroleum ether solvent had least ability to extract phenol from the sample. A study conducted by Simran kaur, 2020 supported the ethanol solvent efficiency in extracting phenol from $C$. guianensis flower [11]. However, in another study infusion aqueous extract of leaf, cold percolation aqueous extract of flower, and maceration methanolic extract of stem of $C$. guianensis were reported to possess more amount of total phenol, thus confirming the influence of method of extraction process in addition to the choice of solvent [12].

Flavonoids are polyphenols and water-soluble, and like phenols reported to possess greater antioxidant activity [13]. In the current study, the values of the flavonoid estimated using reference compound quercetin and are expressed as quercetin equivalent ( $\mathrm{mg} \mathrm{QE} / \mathrm{g}$ ). The result obtained was similar to the phenol content analysis i.e. the ethanol extract had higher amount of flavonoid content (83.18 $\pm 0.604 \mathrm{mg}$ QE/g) (table 1) and reported the ethanol solvent to be good in extracting flavonoid in the sample. However, there was no much difference in the flavonoid content of hydroalcohol extract with respect to ethanol extract. This observation suggested that hydroalcoholic solvent has also exhibited relatively higher ability following ethanol solvent in extracting flavonoid. The petroleum ether extract had the least flavonoid content and hence petroleum ether solvent was considered to be poor in extracting flavonoid in the sample. Apart from fruit pulp, other parts of the plant including stem, leaf and flower were observed to contain flavonoid [14, 15].

Generally various in vitro methods were been employed to examine the antioxidant activities of the sample. But, DPPH radical scavenging activity method is widely and commonly employed to investigate antioxidant activities of bioactive compounds and plant extracts. The potential of the extract to scavenge DPPH radical was evaluated from the degree of discoloration from purple to light yellow. The DPPH radical scavenging activity of different extracts and the standard ascorbic acid was mentioned in table 2. The result of this analysis revealed that not all the solvent fractions had great DPPH scavenging activities at the concentrations ranging from $5 \mu \mathrm{g} / \mathrm{mL}$ to $80 \mu \mathrm{g} / \mathrm{mL}$. Upon comparison it was observed that the radical scavenging activity of the extracts and the ascorbic acid increased with increase in concentration.

Table 2: DPPH radical scavenging activity of different solvent extracts of $C$. guianensis fruit pulp

\begin{tabular}{cccccc}
\hline Concentration $\boldsymbol{\mu g} / \mathbf{m l}$ & Ascorbic acid & Petroleum ether & Chloroform & Ethanol & Hydroalcohol \\
\hline 5 & $15.96 \pm 0.19^{\mathrm{a}}$ & $4.26 \pm 0.16^{\mathrm{a}}$ & $5.43 \pm 0.19^{\mathrm{a}}$ & $12.18 \pm 0.19^{\mathrm{a}}$ & $6.49 \pm 0.13^{\mathrm{a}}$ \\
\hline 10 & $35.81 \pm 0.13^{\mathrm{b}}$ & $6.64 \pm 0.09^{\mathrm{b}}$ & $6.67 \pm 0.16^{\mathrm{b}}$ & $25.73 \pm 0.13^{\mathrm{b}}$ & $10.00 \pm 0.26^{\mathrm{b}}$ \\
\hline 20 & $50.30 \pm 0.16^{\mathrm{c}}$ & $9.54 \pm 0.19^{\mathrm{c}}$ & $8.86 \pm 0.17^{\mathrm{c}}$ & $41.73 \pm 016^{\mathrm{c}}$ & $14.64 \pm 0.13^{\mathrm{c}}$ \\
\hline 40 & $87.39 \pm 0.22^{\mathrm{d}}$ & $14.52 \pm 0.26^{\mathrm{d}}$ & $14.45 \pm 0.16^{\mathrm{d}}$ & $48.45 \pm 0.22^{\mathrm{d}}$ & $21.20 \pm 0.13^{\mathrm{d}}$ \\
\hline 80 & $99.16 \pm 016^{\mathrm{e}}$ & $6.79 \pm 0.23^{\mathrm{e}}$ & $22.49 \pm 0.13^{\mathrm{e}}$ & $60.86 \pm 0.16^{\mathrm{e}}$ & $34.86 \pm 0.16^{\mathrm{e}}$ \\
\hline
\end{tabular}

Values are mean of three replicates. Means followed by same letters are statistically not significant at $\alpha=0.05$ by Tukey test 
However, the concentration at which the extracts had over $50 \%$ inhibitory activity, varies. In this study, ethanol extract at $80 \mu \mathrm{g} / \mathrm{ml}$ showed more than $50 \%$ inhibitory activity. The $\mathrm{IC}_{50}$ values of the extracts ranged from $52.59 \mu \mathrm{g} / \mathrm{ml}$ in the ethanol extract to 277.55 $\mu \mathrm{g} / \mathrm{ml}$ in the petroleum ether extract (fig. 1).

The increasing scavenging activity of the extracts and the standard ascorbic acid was in the following order; Ascorbic acid $>$ ethanol $>$ hydroalcohol $>$ chloroform $>$ petroleum ether. Lower the $\mathrm{IC}_{50}$ value, higher is the scavenging activity. In this context, it had been observed that the ethanol extract had higher scavenging activity compared to other extracts. This finding revealed a favourable relation between phenol and flavonoid and
DPPH scavenging activity. Extracts with higher polyphenolics (phenol and flavonoid) had lower $\mathrm{IC}_{50}$ and hence showed higher radical scavenging activity (fig. 2). Such a correlation was evident in a study conducted with flowers of $C$. guianensis at different floral stages. Flowers at early stages exhibited high polyphenolic content and thus increased antioxidant activity [16]. The present study strongly suggested that fruit pulp have been effective in scavenging free radicals. This observation was in agreement with a study in which crude fruit pulp and fruit pulp gold nanoparticle was compared for their antioxidant potential and both found to possess excellent antioxidant activity [17].

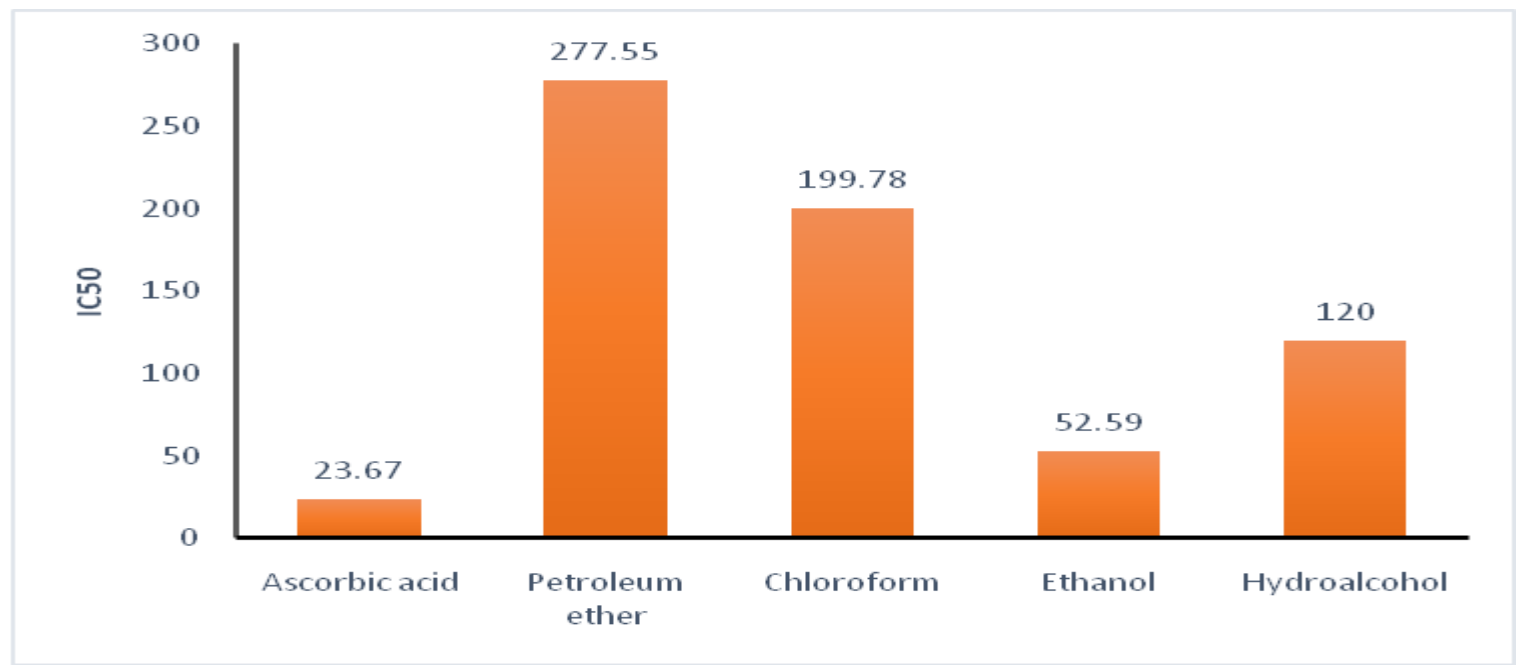

Fig. 1: $\mathrm{IC}_{50}$ values of standard and different solvent extracts of $C$. guianensis fruit pulp
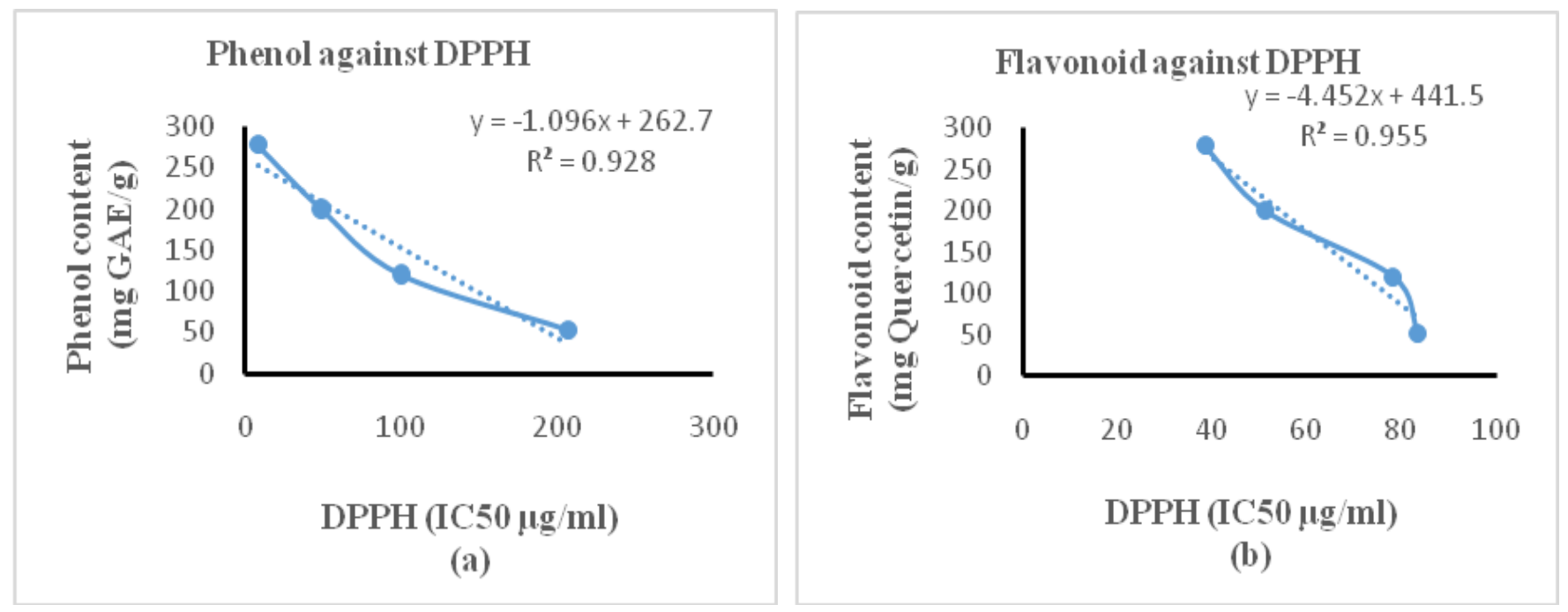

Fig. 2: Correlation of the polyphenolic compounds against the $\mathrm{IC}_{50}$ of the extract (a) Phenol against DPPH (b) Flavonoid against DPPH 
GC-MS analysis was carried only for ethanolic fruit pulp extract as it was proved to be the competent extract containing more amounts of phenol and flavonoid contents and scavenging DPPH radical effectively. The GC-MS chromatogram of ethanolic extract of $C$. guianensis was presented in fig. 3. Interpretation was done based on comparison between the obtained spectra of the unknown compounds with the spectra of the compounds in the database. The analysis has revealed the presence of 30 different compounds belonging to various chemical classes. The name of the identified compounds and other details including their retention time (RT), Molecular weight, Molecular formula and peak area in percentage was presented in table 3. Among the identified compounds, 2,5-Furandione, 3 methyl and 5-Hydroxymethylfurfural were found to be prevalent with a peak area of $35.13 \%$ and $30.92 \%$ respectively. 2,5-Furandione, 3 methyl were reported to be present in pomegranate peel $[18,19]$ and pulp [23] Garcinia dulcis fruit [20], sunflower seed oil, Ceratonia silique fruit [21], Premna integrifolia root [22], and Emblica officinalis Gaertn. [23]. Further, there were reports that explained the anticancer activity of the compound [18, 20]. Similarly 5 -Hydroxymethylfurfural was also seen in Centella asiatica [24], Stemona japonica (Blume) Miq. [25], Antidesma bunius fruit [26], Kalanchoe pinnata [27] and Ziziphus mauritiana fruit [28]. 5-Hydroxymethylfurfural was reported to possess antioxidant [28], antiproliferative [28], antiangiogenic [24], and hepatoprotective activities [24]. Earlier volatile and semivolatile compounds were analyzed in Brazilian ripe $C$. guianensis using solid-phase extraction technique and gas chromatography methods and have identified 50 different compounds with linalool, benzyl alcohol, terpineol, hexadecanoic acid and the cis- and trans-furan linalool oxides being the predominant [29]. GC-MS analysis was also carried out with leaves of $C$. guianensis and able to identify 8 different compounds which belong to the category of polyphenols and nitrogen containing alkaloids [30].

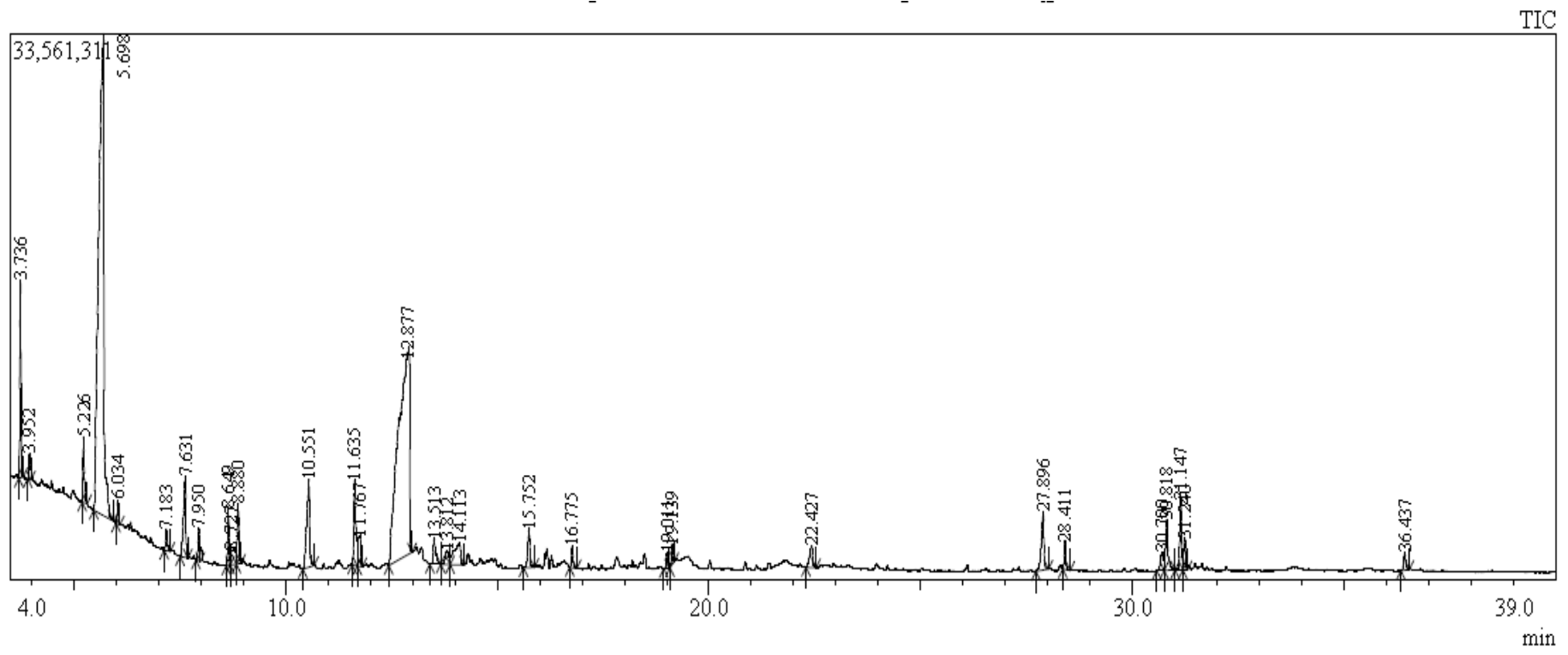

Fig. 3: GC-MS chromatogram of ethanolic extract of $C$. guianensis fruit pulp

Table 3: Chemical compounds identified in the ethanolic extract of $C$. guianensis fruit pulp through GC-MS

\begin{tabular}{|c|c|c|c|}
\hline Peak & R.Time & Area\% & Name \\
\hline 1 & 3.736 & 3.01 & $\begin{array}{l}\text { Name: Furfural } \\
\text { Molecular formula: } \mathrm{C}_{5} \mathrm{H}_{4} \mathrm{O}_{2} \\
\text { Molecular weight: } 96 \\
\text { Nature: Heterocyclic }\end{array}$ \\
\hline 2 & 3.952 & 0.49 & $\begin{array}{l}\text { Name: 2-Butenedioic acid or fumaric acid } \\
\text { Molecular formula: } \mathrm{C}_{4} \mathrm{H}_{4} \mathrm{O}_{4} \\
\text { Molecular weight: } 116 \\
\text { Nature: Dicarboxylic acid }\end{array}$ \\
\hline
\end{tabular}




\begin{tabular}{|c|c|c|c|}
\hline 3 & 5.226 & 1.29 & $\begin{array}{l}\text { Name: Ethanol, 2,2-diethoxy- } \\
\text { Molecular formula: } \mathrm{C}_{6} \mathrm{H}_{14} \mathrm{O}_{3} \\
\text { Molecular weight: } 134 \\
\text { Nature: Alcohol derivative }\end{array}$ \\
\hline 4 & 5.698 & 35.13 & $\begin{array}{l}\text { Name: 2,5-Furandione, 3-methyl- } \\
\text { Molecular formula: } \mathrm{C}_{5} \mathrm{H}_{4} \mathrm{O}_{3} \\
\text { Molecular weight: } 112 \\
\text { Nature: Heterocyclic }\end{array}$ \\
\hline 5 & 6.034 & 0.37 & $\begin{array}{l}\text { Name: 2-Furancarboxaldehyde, 5-Methyl or 5-Methyl furfural } \\
\text { Molecular formula: } \mathrm{C}_{6} \mathrm{H}_{6} \mathrm{O}_{2} \\
\text { Molecular weight: } 110 \\
\text { Nature: Heterocyclic }\end{array}$ \\
\hline 6 & 7.183 & 0.49 & $\begin{array}{l}\text { Name: 1,2-Epoxy-3-(2'-Ethoxy)ethoxy propane } \\
\text { Molecular formula: } \mathrm{C}_{7} \mathrm{H}_{14} \mathrm{O}_{3} \\
\text { Molecular weight: } 146 \\
\text { Nature: Organic acid }\end{array}$ \\
\hline 7 & 7.631 & 2.54 & $\begin{array}{l}\text { Name: Dihydro-3-methylene-2,5-furandione } \\
\text { Molecular formula: } \mathrm{C}_{5} \mathrm{H}_{4} \mathrm{O}_{3} \\
\text { Molecular weight: } 112 \\
\text { Nature: Heterocyclic }\end{array}$ \\
\hline 8 & 7.950 & 0.69 & $\begin{array}{l}\text { Name: 1-Acetoxy-2-Propanol } \\
\text { Molecular formula: } \mathrm{C}_{5} \mathrm{H}_{10} \mathrm{O}_{3} \\
\text { Molecular weight: } \\
\text { Nature: Organic compound }\end{array}$ \\
\hline 9 & 8.649 & 1.04 & $\begin{array}{l}\text { Name: 2-Furaldehyde diethyl acetal } \\
\text { Molecular formula: } \mathrm{C}_{9} \mathrm{H}_{14} \mathrm{O}_{3} \\
\text { Molecular weight: } 170 \\
\text { Nature: Heterocyclic }\end{array}$ \\
\hline 10 & 8.727 & 0.97 & $\begin{array}{l}\text { Name: 2,5-Furandicarboxaldehyde } \\
\text { Molecular formula: } \mathrm{C}_{6} \mathrm{H}_{4} \mathrm{O}_{3} \\
\text { Molecular weight: } 124 \\
\text { Nature: Heterocyclic }\end{array}$ \\
\hline 11 & 8.880 & 1.32 & $\begin{array}{l}\text { Name: 1-(2-Furanyl)-2-Hydroxyethanone } \\
\text { Molecular formula: } \mathrm{C}_{6} \mathrm{H}_{6} \mathrm{O}_{3} \\
\text { Molecular weight: } 126 \\
\text { Nature: Heterocyclic }\end{array}$ \\
\hline 12 & 10.551 & 3.41 & $\begin{array}{l}\text { Name: 1,5-Anhydro-6-deoxyhexo-2,3-diulose } \\
\text { Molecular formula: } \mathrm{C}_{6} \mathrm{H}_{8} \mathrm{O}_{4} \\
\text { Molecular weight: } 144 \\
\text { Nature: Sugar }\end{array}$ \\
\hline 13 & 11.635 & 2.21 & $\begin{array}{l}\text { Name: Napthalene } \\
\text { Molecular formula: } \mathrm{C}_{10} \mathrm{H}_{8} \\
\text { Molecular weight: } 128 \\
\text { Nature: Aromaticc hydrocarbon }\end{array}$ \\
\hline 14 & 11.767 & 1.28 & $\begin{array}{l}\text { Name: Ethyl 2-acetyloctanoate } \\
\text { Molecular formula: } \mathrm{C}_{12} \mathrm{H}_{22} \mathrm{O}_{3} \\
\text { Molecular weight: } 214 \\
\text { Nature: Organic compound }\end{array}$ \\
\hline 15 & 12.877 & 30.92 & $\begin{array}{l}\text { Name: } 5 \text {-Hydroxymethylfurfural } \\
\text { Molecular formula: } \mathrm{C}_{6} \mathrm{H}_{6} \mathrm{O}_{3} \\
\text { Molecular weight: } 126 \\
\text { Nature: Aromatic derivative }\end{array}$ \\
\hline
\end{tabular}




\begin{tabular}{|c|c|c|c|}
\hline 16 & 13.513 & 0.85 & $\begin{array}{l}\text { Name: Butanedioicacid, hydroxy-, diethyl ester, }(+/-) \\
\text { Molecular formula: } \mathrm{C}_{8} \mathrm{H}_{14} \mathrm{O}_{5} \\
\text { Molecular weight: } 190 \\
\text { Nature: Hydroxy acid }\end{array}$ \\
\hline 17 & 13.812 & 0.76 & $\begin{array}{l}\text { Name: 1,2-Cyclopropanedicarboxylic acid } \\
\text { Molecular formula: } \mathrm{C}_{6} \mathrm{H}_{8} \mathrm{O}_{4} \\
\text { Molecular weight: } 144 \\
\text { Nature: Dicarboxylic acid }\end{array}$ \\
\hline 18 & 14.113 & 1.99 & $\begin{array}{l}\text { Name: Malic Acid } \\
\text { Molecular formula: } \mathrm{C}_{4} \mathrm{H}_{6} \mathrm{O}_{5} \\
\text { Molecular weight: } 134 \\
\text { Nature: Hydroxyacid }\end{array}$ \\
\hline 19 & 15.752 & 1.12 & $\begin{array}{l}\text { Name: 6-Hydroxy-2-Oxo-1,2-dihydro-4-pyridine carboxylic acid / 2,6- } \\
\text { Dihydroxyisonicotinic acid } \\
\text { Molecular formula: } \mathrm{C}_{6} \mathrm{H}_{5} \mathrm{NO}_{4} \\
\text { Molecular weight: } 155 \\
\text { Nature: Organic compound }\end{array}$ \\
\hline 20 & 16.775 & 0.48 & $\begin{array}{l}\text { Name: n-Heptadecane } \\
\text { Molecular formula: } \mathrm{C}_{17} \mathrm{H}_{36} \\
\text { Molecular weight: } 254 \\
\text { Nature: Hydrocarbon }\end{array}$ \\
\hline 21 & 19.011 & 0.32 & $\begin{array}{l}\text { Name: Pentadecane } \\
\text { Molecular formula: } \mathrm{C}_{15} \mathrm{H}_{32} \\
\text { Molecular weight: } 212 \\
\text { Nature: Hydrocarbon }\end{array}$ \\
\hline 22 & 19.139 & 0.44 & $\begin{array}{l}\text { Name: 2,4-Di-tert-butylphenol } \\
\text { Molecular formula: } \mathrm{C}_{14} \mathrm{H}_{22} \mathrm{O} \\
\text { Molecular weight: } 206 \\
\text { Nature: Phenol }\end{array}$ \\
\hline 23 & 22.427 & 0.85 & $\begin{array}{l}\text { Name: 1,2,3-Propanetricarboxylic acid, 2-hydroxy-, triethyl ester/ } \\
\text { triethyl citrate } \\
\text { Molecular formula: } \mathrm{C}_{12} \mathrm{H}_{20} \mathrm{O}_{7} \\
\text { Molecular weight: } 276 \\
\text { Nature: Organic compound }\end{array}$ \\
\hline 24 & 27.896 & 2.05 & $\begin{array}{l}\text { Name: n-Hexadecanoic acid } \\
\text { Molecular formula: } \mathrm{C}_{16} \mathrm{H}_{32} \mathrm{O}_{2} \\
\text { Molecular weight: } 256 \\
\text { Nature: Palmitic acid }\end{array}$ \\
\hline 25 & 28.411 & 0.58 & $\begin{array}{l}\text { Name: Hexadecanoic acid, Ethyl ester } \\
\text { Molecular formula: } \mathrm{C}_{18} \mathrm{H}_{36} \mathrm{O}_{2} \\
\text { Molecular weight: } 284 \\
\text { Nature: Terpenoid }\end{array}$ \\
\hline 26 & 30.700 & 0.74 & $\begin{array}{l}\text { Name: 7-Tetradecyne } \\
\text { Molecular formula: } \mathrm{C}_{14} \mathrm{H}_{26} \\
\text { Molecular weight: } 194 \\
\text { Nature: Saturated aliphatic hydrocarbon }\end{array}$ \\
\hline 27 & 30.818 & 1.75 & $\begin{array}{l}\text { Name: 8,11,14-Eicosatrienoic acid, (Z,Z,Z)- or gamma-homolinolenic acid } \\
\text { Molecular formula: } \mathrm{C}_{20} \mathrm{H}_{34} \mathrm{O}_{2} \\
\text { Molecular weight: } 306 \\
\text { Nature: Organic acid }\end{array}$ \\
\hline 28 & 31.147 & 1.69 & $\begin{array}{l}\text { Name: } 9,12 \text {-Octadecadienoic acid }(\mathrm{Z}, \mathrm{Z})- \\
\text { Molecular formula: } \mathrm{C}_{18} \mathrm{H}_{32} \mathrm{O}_{2} \\
\text { Molecular weight: } 280 \\
\text { Nature: Polyunsaturated fatty acid }\end{array}$ \\
\hline
\end{tabular}




\begin{tabular}{|c|c|c|c|}
\hline 29 & 31.240 & 0.73 & $\begin{array}{l}\text { Name: cis, cis, cis-7,10,13-hexadecatrienal } \\
\text { Molecular formula: } \mathrm{C}_{16} \mathrm{H}_{26} \mathrm{O} \\
\text { Moleuclar Weight: } 234 \\
\text { Nature: Organic compound }\end{array}$ \\
\hline 30 & 36.437 & 0.51 & $\begin{array}{l}\text { Nature: Hexadecanoic acid,2-hydroxy-1-(hydroxyl methyl ) ethyl ester (or) 2- } \\
\text { Palmitoylglycerol } \\
\text { Molecular formula: } \mathrm{C}_{19} \mathrm{H}_{38} \mathrm{O}_{4} \\
\text { Molecular weight: } 330 \\
\text { Nature: Organic compound }\end{array}$ \\
\hline
\end{tabular}

\section{CONCLUSION}

The findings of this study are notable, not only in terms of the antioxidant properties of the extracts, but also in terms of their presence of diverse phytochemical components. The data obtained acknowledges $C$. guianensis fruit pulp as a potential source of compounds of therapeutic importance. Furthermore, research in isolation and quantification of the compounds are required to elucidate their various antioxidant mechanisms as well as their natural biological function in vivo.

\section{Conflict of interest}

The authors declare no conflict of interest

\section{REFERENCES}

1. Valli M, Pivatto M, Daniello A, Castro-Gamboa I, Silva DHS, Cavalheiro AJ et al. Quim Nova, 2012; 35:2278-2287.

2. Krishnaiah D, Sarbatly R, Bono A. Biotechnol. Mol. Biol. Rev, 2007; 1:97-104.

3. Weidinger A, Kozlov AV. Biomolecules, 2015; 5: 472-484.

4. Lobo V, Patil A, Phatak A, Chandra N. Pharmacogn Rev, 2010; 4:118-126.

5. Sheba LA, Anuradha V. J Herbmed Pharmacol, 2020; 9:1-11.

6. Mythili K, Umamaheswara RC, Chamundeeswari D, Manna PK. J. Nat. Prod, 2013; 6:141-146.

7. Chandra S, Khan S, Avula B, Lata H, Yang MH, ElSohly MA et al. Evid Based Complement Alternat Mad, 2014; 2014:253875.

8. Ali A, El-Nou M, Yagi SM. J. Genet. Eng. Biotechnol, 2018; 16:677-682.

9. Perumal P, Saravanabhavan K. Asian J Pharm Clin Res, 2018; 1:194-198.

10. Pereira DM, Valentao P, Pereira JA, Andrade PB. Molecules, 2009; 14:2202-2211.

11. Simran K, Priya RI. Int. J. Sci. Res, 2020; 9:7-12.
12. Kaneria M, Rakholiya K, Jakasania R, Dave R, Chanda S. Res. J. Phytochem, 2017; 11:150-169.

13. Kumar S, Sandhir R, Ojha S. BMC Res Notes, 2014; 7:560.

14. Htwe P, Kyu KK, Khaing AA. International European Extended Enablement in Science, Engineering \& Management, 2019; 8:221-232.

15. Akther T, Khan MS, Hemalatha S. Asian J Pharm Clin Res, 2017; 10:354-358.

16. Gupta S, Ghosal M, Choudhury D, Mandal P. J. Pharm. Res. Int, 2014; 4:676-694.

17. Sathishkumar G, Jha PK, Vignesh V, Rajkuberan C, Jeyaraj M, Selvakumar M et al. J. Mol. Liq, 2016; 215:229-236.

18. Mohammed GJ, Al-Jassani MJ, Hameed IH. Int. J. Pharmacogn. Phytochem. Res, 2016; 8:480-494.

19. Mohamad T, Khalil A. J. Phytopathol, 2014; 42:171186.

20. Abu Bakar MD, Ahmad NE, Suleiman M, Rahmat A, Isha A. BioMed Res. Int, 2015; 2015:916902.

21. Eltayeib AA, Mohamed MSA. J Nat Ayurvedic Med, 2019; 3:000213.

22. Mali PY. Chron Young Sci. 2014; 5:53-58.

23. Manikandaselvi S, Brinda P, Nandini S, Saralla RP. Int J Pharm Pharm Sci. 2014; 6:63-69.

24. Bhuyar P, Rahim MHA, Maniam GP, Govindan N. J Microbiol Biotech Food Sci, 2021; 10: 631-635.

25. Ni J, Ren Q, Luo J, Chen Z, Xu X, Guo J et al. Exp. Parasitol, 2020; 217:107955.

26. Yelliantty Y, Kartasasmita RE, Surantaatmadja SI, Rukayadi Y. Food Sci. Technol (Campinas), 2021.

27. George LO, Radha HR, Somasekariah BV. Indian J. Chem, 2018; 57B:1213-1221.

28. Kushwaha P, Yadav SS, Singh V, Dwivedi LK. Int J Pharm Sci\& Res, 2019; 10:2911-2916.

29. Lavanya R, John A. Int. J. Phytopharm, 2015; 5:8185.

30. Maithe C. de Araujo, Pinheiro, Teixeira, Riachi LG, Rocha CB, Maria. Nat Prod J, 2014; 4:280-284. 